Portland State University

PDXScholar

\title{
Creating Successful French Immersion Programs in North America
}

Katherine Modlin

Portland State University

Follow this and additional works at: https://pdxscholar.library.pdx.edu/honorstheses Let us know how access to this document benefits you.

\section{Recommended Citation}

Modlin, Katherine, "Creating Successful French Immersion Programs in North America" (2019). University Honors Theses. Paper 792.

https://doi.org/10.15760/honors.810

This Thesis is brought to you for free and open access. It has been accepted for inclusion in University Honors Theses by an authorized administrator of PDXScholar. Please contact us if we can make this document more accessible: pdxscholar@pdx.edu. 


\section{Creating Successful French Immersion Programs in North America}

By

Katherine Modlin

An undergraduate honors thesis submitted in partial fulfillment of the requirements for the degree of

Bachelor of Arts

in

University Honors

and

Applied Linguistics

Thesis Adviser

Steven L. Thorne, Ph.D.

Portland State University 


\begin{abstract}
Language immersion education (with various related approaches called bilingual and dual-language education) is a complex topic that includes many different linguistic, educational, social, and political facets. There has been much debate about the best method with which to educate children in a language that is not their mother tongue. While the goal of language immersion education is to immerse a child in the second language, in order for the child to be bilingual there must remain a support system for their first language. Many researchers have sought to determine the best way to achieve these two goals, to gain a second language while also maintaining and enhancing a child's home language. The results of these studies are diverse, but findings from second language acquisition research can help to create conditions for successful language immersion education. While it is by no means exhaustive, as new studies are being published everyday, this synthesis of language immersion research and pedagogical models, drawing primarily on research focusing on K-5 French immersion education in the U.S. and Canada, hopes to provide a clear overview of research-informed approaches for language immersion education in the North American context.
\end{abstract}




\section{Introduction}

In a progressively globalized world, learning and mastering a second language is an important skill. As it becomes increasingly necessary for citizens of the world to interact and understand each other, it also becomes necessary for the world's citizens to speak multiple languages (Hall, Smith, \& Wicaksono, 2011). All countries in the world, including the United States, are comprised of multilingual populations to a greater or lesser degree. In the U.S., we have a large Spanish speaking population as well as numerous other minority language populations. Where the United States differs from other countries of the world is that second language learning is often not mandatory and in some instances is not even encouraged, creating a disparity between the United States and other developed countries (Hickey \& de Meija, 2014). The focus of this thesis, a review of research on language immersion education in the U.S. and Canada, is one way to remedy this disparity.

The impetus to send a child to an immersion school is often due to the parents' view of being bilingual as a social, political, and professional advantage (Bialystok, Peets, \& Moreno, 2014). This fact is especially true in Canada, where French is an official language, although a growing number of Americans are beginning to realize how advantageous having a second language can be in modern society. Generally, students in immersion classrooms are taught primarily in a language that is not their native language (henceforth known as first language or L1) although there are some exceptions (Au-Yeung, Hipfner-Bocher, Chen, Pasquarella, D'Angelo, \& S. Helene, 2014; Deacon, Commissaire, \& Chen, 2013; Wise \& Chen, 2015). In immersion education there is typically a primary or target language of instruction and the majority (from $100 \%$ in full immersion programs to $50 \%$ in dual language or bilingual programs) of classes and social interaction are conducted in the target language (L2). Immersion in the L2 
starts immediately, though the students do not speak the target language, with the expectation and knowledge that the children will come to understand the target language. It is important to note that students are not thrown into this educational setting and expected to understand the teacher without assistance. Educators are certainly aware that students cannot initially understand the target language so they use simple language, consistent grammatical forms, and translanguaging as methods of facilitating understanding in the classroom (Akcan, 2004).

Immersion education in the United States is a complex topic of study. Like any area of the field of linguistics, there are several aspects to a problem and multiple ways a subject can be studied. While there exists a large body of literature on immersion education (Au-Yeung, Hipfner-Bocher, Chen, Pasquarella, D'Angelo, \& S. Helene, 2014; Bialystok, Peets, \& Moreno, 2014; Jared, Cormier, Levy, \& Wade-Woolley, 2011; Nicolay \& Poncelet, 2013), both the methods and the finding of studies show considerable heterogeneity. There are case studies and longitudinal studies of immersion classrooms. There are pedagogical studies, general qualitative studies on immersion education, and large quantitative empirical studies. In this paper I develop a critical review of research on immersion language education. This will bring together a number of research literatures written on the subject, bringing together results on successes and failures in the multiple areas of immersion education and related programs such as dual language and bilingual education. This following analysis is done with the goal of establishing a framework for immersion education that could help to inform specifically French language immersion in the United States.

\section{Literature Review}

Before proceeding, it is necessary to make a brief distinction between immersion learning in Canada and the United States. As French is an official language of Canada, students who 
speak French at home and wish to be educated in French do not attend immersion schools, they attend French language schools, where English is taught as a second language (more closely related to how one might study French as a foreign language here in the U.S.) (Wise, D'Angelo, \& Chen, 2016). Students at French language Canadian immersion schools typically have English as their native language (L1); however, in the United States French immersion schools often include a mix of children speaking either French or English at home (or any number of other languages).

It is also necessary to elucidate the different types of language immersion education that exist, as the research that has been compiled focuses on different types of immersion learning. The most common approach to immersion learning begins with total or near total immersion in the target language, wherein the target language is implemented from the moment students arrive in Kindergarten or first grade. Even though the children do not yet speak the language, research has shown that with enough input these students start to produce some output and begin to comprehend what they are being asked (Hickey \& de Meija, 2014). Language immersion models generally include support in the development of academic literacy in two languages. In the U.S., within language immersion programs conducted in Chinese, Russian, Spanish, French, and Japanese (to take examples from the state of Oregon), English Language Arts classes are included in order to maintain proficiency in their mother tongue (or language of wider communication for students with different home languages). In some language immersion programs, challenging content-based subjects like math and science are taught in the target language (for example French) (Akcan, 2004). This has proven to be a challenge as the concepts presented in these subjects are often complex, and it can be difficult for students trying to learn in an unfamiliar language. Studies have shown that utilizing the child's stronger (or L1/home) 
language and its accompanying encoding skills, meaning the orthographic tactics one uses to identify words both familiar and unknown, have been proven to be effective in helping the child grasp difficult concepts in the second language (Turnbull, Cormier, \& Bourque, 2011). This research suggests that the teacher and the students should use both their L1 and their target language for instruction in some subjects (particularly math). Numerous immersion programs have remedied this difficulty by creating a $90-10,80-20$, or $70-30$ split between the target language and L1, meaning all classes are in the target language with the exception of math, science, and English Language Arts.

\section{Why choose language immersion education?}

Research shows that children who participate in language immersion programs reach high levels of proficiency in their target language while simultaneously maintaining progress in their native language and learning subject matter content at the same rate as their monolingual peers (Day \& Shapson, 2005). In other words, the children being taught in a language that is not their mother tongue are still receiving the same knowledge as students who are not bilingual; there is no decrease in the quality of education caused by the use of a foreign language. This is an important finding as those who are opposed to immersion education generally express fear that dual immersion retards the development of the child's first language. One point to concede is that students in immersion classrooms lag behind when it comes to learning grammatical concepts in both languages earlier in their schooling, but it is of note that the children do not fall behind in other areas of mastering their native language, and they do eventually master these grammatical concepts and perform as well as monolingually educated students by the time they reach High School (Jared, Cormier, Levy, \& Wade-Woolley, 2011). 
The societal and professional benefits of having a foreign language immersion education are also not to be overlooked (Bialystok, Peets, \& Moreno, 2014; Au-Yeung, Hipfner-Bocher, Chen, Pasquarella, D'Angelo, \& S. Helene, 2014; Genessee, 1987). With the advancement of technology we are all becoming much more connected to each other than we have been in the past. This facilitates a need for more of the world's citizens to become multilingual and also indicates that in the future more jobs will require people to speak more than one language. Another interesting point surrounding the societal advantages of a having a large multilingual population is the fact that this increases the linguistic competency of a nation, leading to a society that is more accepting of linguistic diversity, and by extension more accepting of diversity in other forms (Christian, 1996).

\section{Challenges and concerns surrounding immersion education}

\section{Early intervention for struggling readers}

One issue that seems to be unique to immersion education is a difficulty supporting children who struggle to read. This is because students are learning to read and write both their L1 and target languages. Therefore, aiding language immersion students who are falling behind their peers in reading presents a challenge for educators (Wise, D'Angelo, \& Chen, 2016). Firstly, finding pedagogically and linguistically qualified teachers for an immersion classroom is difficult. While most student teaching programs only focus on education in one language, immersion teachers must be fully competent in at least two languages (the target and source) and perform well pedagogically (Buyl \& Housen, 2014). Adding an additional task of identifying and assisting struggling readers is difficult for the educator as they may not be equipped to recognize the signs that a child is having difficulty reading (Wise \& Chen, 2015). 
Additionally, French immersion programs (and compulsory education in francophone countries) focus primarily on listening and speaking proficiency, focusing on reading proficiency in later grades (Buyl \& Housen, 2014). Because immersion education is already considered a unique form of education, there are no special programs to assist children who may be struggling within an immersion school. In Canada, where immersion schools have long been commonplace, children who are struggling with reading proficiency are encouraged to go back to an English learning track. This prevents the child from ever truly being bilingual as early language intervention is necessary to provide native-like proficiency (Van Herk \& Rees-Miller, 2010). Children who have reading issues initially, but who might improve with specialized teaching practices, are effectively shut out from the opportunity to learn a second language (Wise, D'Angelo, \& Chen, 2016).

\section{Development of $L 1$}

Another area of concern for those involved in the field of immersion education is ensuring sufficient development of the students' L1, without which the child will not truly be bilingual (Roy \& Galiev, 2011). In full language immersion programs, every interaction the pupil has, whether with peers or their teachers, and all of the instruction they receive in content area subjects, is meant to take place in the target language. Under these conditions, the students are immersed in the target language. Equally important, however, is that students also receive support in their native language (or language of wider communication if that is not their home or native language). The biggest hindrance to this is that children participating in French immersion programs develop reading ability somewhat later than students in monolingual educational settings (Buyl \& Housen, 2014). Because children in immersion programs have little to no knowledge of the target language, and additionally are living and learning in two languages 
rather than one, teachers focus first on acquiring oral and auditory proficiency before moving on to reading instruction (Wise, D'Angelo, \& Chen, 2016). This means that English language instruction, and specifically learning to read in English, is co-occurring with learning to read in French. In essence, children in language immersion and bilingual/dual language programs are learning and processing two languages simultaneously and hence have a higher cognitive load than do students in monolingual educational settings. Educators have recognized the need for the students to receive formal instruction in their native language of English, therefore most immersion programs begin to incorporate English language classes into their curriculum around second or third grade (Turnbull, Cormier, \& Bourque, 2011). Other aspects of language learning in English, like speaking and listening, are not as critical as many of the children receive English input at home, through access to media, and more broadly in society.

\section{Reluctance towards using the target language (L2)}

An overriding issue facing immersion education is the reluctance of students to use the target language (French) with peers in a school setting after a certain age (Macintyre, Burns, \&

Jessome, 2011). Studies have shown from grades K-2, children communicate almost exclusively in French with their teachers and peers (even if it is somewhat rudimentary), but starting around third or fourth grade, many students start to switch to English to communicate amongst themselves (Macintyre, Burns, \& Jessome, 2011; Turnbull, Cormier, \& Bourque, 2011). This predicament has long puzzled researchers - one would assume the more they are exposed to French the more inclined students would be to use French not just as the language of the classroom but also the medium of communication outside of the classroom (Tarone \& Swain, 1995). Recent qualitative studies, (Macintyre, Burns, \& Jessome, 2011) (Turnbull, Cormier, \& 
Bourque, 2011) including interviews with students, have given some perspective on this phenomenon.

Before diving into the reasons why this happens, a brief explanation of speech variation and speech communities is necessary to better understand the reluctance of older students to use their L2 among peers. Speech communities are defined as a sociologically similar group that speak the same variety (or dialect) of a language, the same slang or jargon is used, and their grammar/linguistic variations are similar (Van Herk \& Rees-Miller, 2010). These sociological similarities vary and can include but are not limited to: age, gender, race, social class, and geography. Within a given speech community there are any given number of registers in use. Registers are best described as the level of formality with which one addresses someone (Van Herk \& Rees-Miller, 2010). Think of the dozens of different interactions we have with others each day: we speak differently with the clerk at the grocery store than we do with our mothers, and we speak differently with our friends than with our family. Written language has registers too: this academic paper is written differently than it would be if it were a magazine article on second language immersion. So what does this have to do with immersion students not using their L2 amongst themselves? The issue at present is that the only language input the students are receiving is from the teacher, as they are native English speakers speaking English at home and living in an English speaking community (Tarone \& Swain, 1995). Students are only receiving input at the academic register - they aren't necessarily learning colloquialisms and slang, and they are learning only standard academic registers because this is what is available in a purely academic setting (Macintyre, Burns, \& Jessome, 2011). They do not want to speak to their friends in the same way that they would address the teacher, but the only language they have at their disposal is that of a teacher/student relationship. Registers can be taught to a certain extent; 
however, language learning focuses on learning "standard" grammar and speech (although who determines what is standard is a highly political endeavor). There have been numerous solutions proposed to solve this problem that will be discussed more in depth in the Framework section of this paper.

\section{Accessibility to immersion education}

Language immersion education has proven to be extremely beneficial for cognitive development in its students, including benefits in executive function and perspective taking that extend across the lifespan (Bialystok, Peets, \& Moreno, 2014), but one would be remiss not to acknowledge a number of accessibility-limiting issues surrounding immersion education. One aspect that has already been briefly mentioned is the lack of resources for students who require a special educational setting. Immersion education programs and schools are considered by many to be outside of the realm of what one might call "mainstream" education and as a result, little consideration is given to the fact that there are students who may need additional help to arrive at the same level as their peers academically. There are virtually no special education programs for students in an immersion setting in the U.S., and in Canada, where immersion education is much more regulated and widespread, the students who are identified as struggling readers are encouraged to return to an English language only track (Genessee, 1987). It is quite possible that with a little assistance, these children may be able to achieve the same level as their peers, but after about grade three or four, the likelihood of becoming completely bilingual with native-like fluency in both languages begins to decrease (Archibald, 2010).

Another issue surrounding the inaccessibility of immersion education, especially in the U.S., is that the majority of French immersion schools are privately operated (Wise \& Chen, 2015). This prevents a whole group of children of lower socioeconomic status from pursuing 
bilingualism in their early years, when second language learning is most critical for true bilingualism (Archibald, 2010). However, with the influx of more and more Spanish speaking migrants into the U.S., many public schools have either shifted completely to a bilingual program or have an option for students to follow a bilingual course of study. This is a recent trend and is widespread only in select U.S. states, though the prevalence of language immersion and bilingual options is slowly growing. Especially for certain languages, such as French and German in the U.S., it appears that the opportunity of a bilingual education often seems to be a privilege reserved for those with the means and resources to pay private school tuition.

\section{Other approaches: Dual language and bilingual language programs}

Differing from total immersion is dual language immersion, which overlaps with programs called bilingual education. Bilingual and dual language programs typically involve a 50-50 split between two instructional languages (e.g., French and English or Spanish and English). While the primary focus of this paper is on immersion education, studies focusing on dual and bilingual language programs are helpful within the larger context of immersion education as a whole.

Dual and bilingual education is straightforward in meaning - there are two languages of instruction within the classroom (Lee, Hill-Bonnet, \& Raley, 2011) and a stated goal is to achieve "additive bilingualism" wherein the language of wider communication (i.e., English) as well as the target or minority language (i.e., French or Spanish) is also maintained and

instructionally enhanced. These types of immersion programs are most often found in areas with large Hispanic populations. These children speak Spanish at home but need to eventually learn English in some capacity. The Hispanic population in the United States is the fastest growing minority population in the country and 1 in 5 school age children are Hispanic (Gonzalez, 2012). 
With this new influx of immigrants and their children who are born in the United States comes a need for linguistic support not only in learning English as a second language but also in maintaining the Spanish they already know and providing continuing support for that language. In this respect, dual language immersion provides an excellent opportunity for both Spanish and English to be supported. The language of instruction in these classrooms is often a 50/50 split between the two languages, but how they split the languages varies. Some schools have two teachers in each classroom, one who speaks one language and another who speaks the other. Other schools split the languages between days or subjects of study.

Recent studies (Au-Yeung, Hipfner-Bocher, Chen, Pasquarella, D'Angelo, \& S. Helene, 2014; Stevahn, Munger, \& Kealey, 2005) have found many observable advantages to dual language immersion besides the obvious advantage of supporting both the child's native and second language. Providing linguistic support for both languages helps to bridge the social gap between these two speech communities (Christian, 1996). Another principal effect of having a classroom of children with different linguistic backgrounds is that it breeds tolerance. Children work and learn together and in doing so learn that even though they may have started out being quite different and not being able to understand each other, their differences really are not so enormous in the end (Hickey \& de Meija, 2014).

\section{A proposed framework for facilitating bilingual education}

The growing research base illustrates the "bilingual advantage," or the cognitive, social, and professional benefits afforded by language immersion and bilingual education. The goal of this paper is to synthesize the large and growing research base showing the benefits of language immersion and bilingual education and to use it to help educators in immersion programs in a 
meaningful way. This is a complex issue as there are a broad range of factors that contribute to learning a language and it takes years to thoroughly study just one of these aspects. In addition, every child has a different knowledge base when they start school and there are many external factors at play when it comes to learning a language. One's home life and how much language exposure they receive is a crucial indicator of how children will acquire not only a second language, but also their first (O'Grady \& Cho, 2010). This discussion below is by no means the final word on the best course of action for an immersion education, as there are multitudes of studies that continue to be published that address this topic. What follows is a discussion of the methods that have shown marked results for immersion students.

The most important part of any language learning, especially immersion education, is the creation of a safe and nurturing environment in which children can learn the language. It is imperative that pupils are not afraid to take risks when it comes to their language production because inevitably beginning learners of a new language make many mistakes (Akcan, 2004). Of equal importance at the beginning stages of immersion education is the use of routines and prefabricated patterns to assist in learning the language as the children are starting out with little to no knowledge of the target language (Vesterbacka, 1991). When children can recognize and use these prefabricated forms, it helps to build their confidence in their use of the L2. A significant part of this pattern building is that the teacher creates meaningful classroom routines that gradually incorporate more and more of the target language. For example: when children enter the room on the first day of school the teacher greets them, in the target language, and asks simple questions such as their name and how their morning is. The next day they might add another question such as "What is your favorite color?" and so on and so forth adding more each day. Obviously this is a very narrow example as more than just a name needs to be covered on 
the first day of school, but building a consistent routine has been proven to be an effective method (Akcan, 2004).

Equally as important as creating a predictable routine is placing significant emphasis on communicating in the target language and producing meaningful content for the students. It is vital that the teacher makes students aware that even in the early stages they are to use the target language as much as possible (Vesterbacka, 1991). This places the child in the habit of using their L2 whenever possible. Both purposeful content and production are also important factors to ensure successful second language acquisition. Christian (1996) found that language is "best developed within a content-based curriculum rather than as the object of classroom instruction." What does that mean in an actual real world application? Traditional foreign language education is focused on teaching the aspects of a language as the content of class. Most effective with immersion education, however, is using the language as a medium of instruction rather than as the focus of the lesson (Akcan, 2004). In a typical high school French class where the subject of study that day is weather, the teacher may start by doing a vocabulary review of the necessary terms, then moves on to the unique formulas involved to describe the weather in French, and finally the teacher wraps the subject up with a review or an activity. Conversely, in an immersion classroom the teacher should focus on teaching the children about the weather while using French. Discussing, say, how tornadoes and hurricanes are formed as opposed to simply teaching the pupils the words for hurricane and tornado. It is also important for immersion teachers to provide opportunities within the lesson for students to have sustained use of the language, as the more that students speak in the target language the more opportunity there is to expand one's linguistic complexity (Swain, 1988). The ultimate goal of all of these techniques (routine building, creation of a safe space, and centering on a content-based curriculum) is to manufacture 
a situation in which the students feel completely comfortable to produce as much of the target language as possible, whether they make mistakes or not.

Another issue that must be addressed is the reluctance of children to use the L2 amongst themselves after a certain age, and acknowledging that this is not for lack of trying on the teachers' part. An integral part of immersion education is that children produce as much of the target language as possible. Though teachers in these situations encourage and expect children to speak in the L2 whenever possible, you can't force a child to speak in a certain language especially if the teacher is not around. One solution to this issue, especially if the child is asking a question of the teacher that is not in the target language, is to not acknowledge the student until they do speak in the target language (Lee, Hill-Bonnet, \& Raley, 2011). Again this is difficult to enforce on a peer-peer level and admittedly in a classroom of 20 or more children. The overarching issue here is that students do not want to speak to peers the same way that they would speak with the teacher. Therefore they use their L1 because that is the speech community to which they have the most exposure. In an attempt to provide the children with more L2 input on a peer-peer level, many schools have started pen pal programs and digital virtual exchanges with students in francophone countries. Other solutions include having guest speakers come in and spend the day with the class, speaking in a register different from that of the normal classroom (Turnbull, Cormier, \& Bourque, 2011). In Canada researchers have found that organizing cultural meet-ups between native French speakers and immersion students has been quite successful, as this gives the opportunity for the students to learn how to address their peers in the target language (Tarone \& Swain, 1995).

While it is beyond the scope of this paper to completely solve every single issue around immersion education, it is important to acknowledge and address the lack of support for children 
requiring special education (Wise \& Chen, 2015; Wise, D'Angelo, \& Chen, 2016) (Genessee, 1987). As previously stated, in Canadian immersion programs children who are struggling to read are encouraged to return to a monolingual English learning track. This ends their chances of ever becoming truly bilingual, as those first few years of language learning are crucial to fluency (Archibald, 2010). But why should immersion learning be reserved for only those children who do not have any reading challenges? As stated before, there are numerous benefits to being bilingual in modern society. Keeping those with learning difficulties from gaining these same advantages is ensuring that they remain in the same place they started (Genessee, 1987).

Teaching in a special education context through the medium of a non-native language, while also ensuring that the students are learning at the right pace and understanding is undoubtedly a challenge. This is a great topic for further investigation, as there exists very little data on how to conduct special education within an immersion program. Wise \& Chen (2015) did identify some tactics that helped to identify and assist struggling readers, which may aid somewhat in developing a special education language immersion curriculum. They found that supplemental phonological awareness training and small group instruction are effective tools when it comes to assisting struggling readers, with the added benefit of still keeping all students on track academically. Most important, however, is that more research is done to determine even more effective tools for educating those who might need some extra help.

\section{Caveats and limitations of this review of language immersion and bilingual education} research

There exists a wealth of knowledge surrounding immersion and bilingual education, as well as other related topics such as second language acquisition, so narrowing down the scope of this critical review of language immersion and bilingual education research was initially quite 
difficult. The selection process first began with a general search on French immersion education to determine how broad the scope of information was. The articles chosen for this paper were all found using the PSU database or were found as the citations in other articles, and every article was verified as peer-reviewed and was available online for public access. The keywords used to find articles were: bilingual classrooms, early immersion education, immersion education, French immersion, and immersion classrooms. While the topic of this paper is focused on total immersion classrooms, research on related areas such as dual language and bilingual education shed light on issues surrounding language immersion education as well. The focus then turned to narrowing that scope by finding articles that had both qualitative and quantitative results and were not simply case studies of a single immersion classroom. Though those case studies did provide some insight into what type of research would be best suited for this project, single classroom case studies would not be big enough for that information to be generalized to larger immersion education populations. Studies focusing on the development of specific linguistic features were also omitted because the scope of that research would be too narrow to assist with the goal of this project.

\section{Conclusion}

Immersion education is a complex topic of study and no single paper could hope to encompass every aspect of it. The review of research and pedagogical guidelines enumerated in this paper are meant to serve as a resource for determining effective ways to produce bilingual speakers and to highlight some of the issues that have yet to be resolved within the immersion 
education community. Going forward it would be interesting to see more research conducted on the accessibility issues surrounding immersion education, as that seems to be the area lacking the most information. In today's society, having exposure to a second language is becoming more and more crucial, and therefore should not be a privilege reserved for the few. 


\section{Bibliography}

Akcan, S. (2004). Teaching Methodology in a First-Grade French- Immersion Class . Bilingual Research Journal , 28 (2), 267-277.

Archibald, J. (2010). Second Language Acquisition. In W. O'Grady, J. Archibald, M. Aronoff, \& J. Rees-Miller, Contemporary Lingusitics: an Introduction (pp. 391-428). Boston, MA: Bedford/St. Martin's.

Au-Yeung, K., Hipfner-Bocher, K., Chen, X., Pasquarella, A., D'Angelo, N., \& S. Helene, D. (2014). Development of English and French Language and Literacy Skills in EL1 and EL French Immersion Students in the Early Grades . Reading Research Quarterly, 50 (2), 233-254.

Bialystok, E., Peets, K. F., \& Moreno, S. (2014). Producing bilinguals through immersion education: Development of metalinguistic awareness . Applied Psycholinguistics , 35, $177-191$.

Buyl, A., \& Housen, A. (2014). Factors, processes and outcomes of early immersion education in the Francophone Community in Belgium . International Journal of Bilingual Education and Bilingualism, 17 (2), 178-196.

Christian, D. (1996). Two-Way Immersion Education: Students Learning through Two Languages. The Modern Language Journal , 80 (1), 66-76.

Coyoca, A. M., \& Lee, J. S. (2009). A Typology of Language-Brokering Events in DualLanguage Immersion Classrooms . Bilingual Research Journal , 32 (3), 260-279. 
Day, E. M., \& Shapson, S. M. (2005). Integrating Formal and Functional Approaches to Language Teaching in French Immersion: An Experimental Study. Language Learning, 47-80.

Deacon, S., Commissaire, E., \& Chen, X. (2013). Learning about print: the development of orthographic processing and its relationship to word reading in first grade children in French immersion . Reading and Writing , 26, 1087-1109.

Deacon, S., Wade-Woolley, L., \& Kirby, J. (2007). Crossover: The Role of Morphological Awareness in French Immersion Children's Reading . Developmental Psychology , 43 (3), 732-746.

Genessee, F. (1987). Learning Through Two Languages: Studeis of Immersion and Bilingual Education. Cambridge: Newbury House Publishers.

Gonzalez, V. (2012). Assessment of Bilingual/ Multilingual Pre-K-Grade 12 Students: A Critical Discussion of Past, Present, and Future Issues . Theory into Practice , 51 (4), 290-296.

(2011). Why do we use different languages? In C. J. Hall, P. H. Smith, \& R. Wicaksono, Mapping applied linguistics: s guide for students and practitioners (pp. 1-4). New York, NY, USA: Routledge.

Hickey, T. M., \& de Meija, A.-M. (2014). Immersion education in the early years: a special issue . International Journal of Bilingual Education and Bilingualism , 17 (2), 131-143.

Jared, D., Cormier, P., Levy, B. A., \& Wade-Woolley, L. (2011). Early Predictors of Biliteracy Development in Children in French Immersion: A 4-Year Longitudinal Study . Journal of Educational Psychology, 103 (1), 119-139. 
Lee, J. S., Hill-Bonnet, L., \& Raley, J. (2011). Examining the Effects of Language Brokering on Student Identities and Learning Opportunities in Dual Immersion Classrooms . Journal of Language, Identity \& Education, 10 (5), 306-326.

Macintyre, P. D., Burns, C., \& Jessome, A. (2011). Ambivalence About Communicating in a Second Language: A Qualitative Study of French Immersion Students’ Willingness to Communicate. The Modern Language Journa , 95, 81-96.

Mougeon, R., \& Rehner, K. (2001). Acquisition of Sociolinguistic Variants by French Immersion Stuents: The Case of Restrictive Expressions, and More. The Modern Language Journal , 85, 398-415.

Nicolay, A.-C., \& Poncelet, M. (2013). Cognitive abilities underlying second-language vocabulary acquisition in an early second-language immersion education context: A longitudinal study . Journal of Experimental Child Psychology, 115, 655-671.

O'Grady, W., \& Cho, S. W. (2010). FIrst Language Acquisition. In W. O'Grady, J. Archibald, M. Aronoff, \& J. Rees-Miller, Contemporary Linguistics: An Introduction (pp. 351-389). Boston, MA: Bedford/St. Martin's.

Roy, S., \& Galiev, A. (2011). Discourses on Bilingualism in Canadian French Immersion Programs . The Canadian Modern Language Review/La revue canadienne des langues vivantes , 67 (3), 351-376.

Roy, S., \& Schafer, P.-C. (2015). Reading as a skill or as a social practice in French immersion? . Language and Education, 29 (6), 527-544.

Stevahn, L., Munger, L., \& Kealey, K. (2005). Conflict Resolution in a French Immersion Elementary School. The Journal of Educational Research, 99 (1), 3-18. 
Swain, M. (1988). Manipulating and Complementing Content Teaching To Maximize Second Language Learning . TESL Canada Journal , 6 (1), 68-83.

Tarone, E., \& Swain, M. (1995). A Sociolinguistic Perspective on Second Language Use in Immersion Classrooms . The Modern Language Journal , 79 (2), 166-178.

Turnbull, M., Cormier, M., \& Bourque, J. (2011). The First Language in Science Class: A QuasiExperimental Study in Late French Immersion . The Modern Language Journal , 95, 182198.

Van Herk, G., \& Rees-Miller, J. (2010). Language in Social Contexts. In W. O'Grady, J. Archibald, M. Aronoff, \& J. Rees-Miller, Contemporary Linguistics an Introduction (pp. 485-526). Bostin, MA: Bedford/St. Martin's.

Vesterbacka, S. (1991). A conclusion to be drawn from the analysis is that a very important didactic task for the teacher is to provide the children with meaningful routines, in which the role of the second language, both quantitatively and qualitatively is gradually increased. . Journal of Multilingual and Multicultural Development , 12 (1-2), 35-43.

Wise, N., \& Chen, X. (2015). Early Intervention for Struggling Readers in Grade One French Immersion . The Canadian Modern Language Review/ La revue canadienne des langues vivantes , 71 (3), 288-306.

Wise, N., D'Angelo, N., \& Chen, X. (2016). A school-based phonological awareness intervention for struggling readers in early French immersion . Reading and Writing , 29, 183-205.

Writing the method section of a systematic literature review in a dissertation. (n.d.). Retrieved 2018, from University of Bedfordshire: https://lrweb.beds.ac.uk/_data/assets/pdf_file/0005/502169/Writing-the-method-sectionof-a-systematic-lit-review-in-a-dissertation.pdf 